\title{
The Rise of Bilateralism in Trade and its Implications for Pakistan
}

\section{Irfan ul Haque*}

\begin{abstract}
This paper examines and critiques the worldwide mushrooming of preferential trading arrangements and traces its implications for Pakistan. It points out that this development is fundamentally contrary to the principle of most-favored-nation (MFN) treatment, which was the cornerstone of the post-war multilateral trading system as embodied in the General Agreement on Tariffs and Trade (GATT) and by the World Trade Organization (WTO). The causes of the rise in bilateral and regional trading arrangements are discussed and it is shown that they pose a real threat to many relatively small economies, including Pakistan. The paper discusses the various preferential trade agreements Pakistan has already signed. It notes that, with the exception of its trade agreement with China, Pakistan has not succeeded in concluding preferential trading arrangements with any of the strategically and systemically more important countries, viz., the US, European Union, and Gulf Cooperation Council (GCC). The South Asia Free Trade Area (SAFTA) could potentially be of considerable importance for Pakistan's long-term economic growth, but this potential might not be realized if India and Pakistan fail to overcome their mutual differences. Finally, the paper explores steps that might be taken to promote Pakistan's economic interests in its bilateral relations. It points out that, apart from achieving a measure of macroeconomic stability, Pakistan needs to improve its international competitiveness through productivity improvements and be more strategic in its trading relations. Its market access to leading industrial countries that are entering free trade agreements (FTAs) with Pakistan's competitors is a real threat and remedial actions are required.
\end{abstract}

JEL Classification: F13, P45.

Keywords: Trade, Pakistan, growth.

Pakistan has entered into a series of bilateral and regional trade agreements in recent years. This is in line with the observed rise in such

${ }^{*}$ Special Advisor Financing for Development, South Centre, Geneva. 
agreements internationally. The number of special trading arrangements between and among countries is difficult to estimate, but probably now exceeds 1,000 . However, barely 400 of the agreements (proposed or signed) have been notified to the World Trade Organization (W'TO) (Herrmann 2008). Mongolia is the sole country that has not yet entered into any bilateral or regional agreement.

In short, regional or bilateral trading agreements (BTAs) have now become the dominant mode of international commerce, and their importance continues to grow. For example, the European Union at present has trade relations with only six countries that are based on the mostfavored-nation (MFN) treatment principle $^{1}$ (Bhagwati 2008). The rise of bilateralism and regionalism in trade gives rise to a number of questions:

- Are such arrangements in conformity with the established multilateral trading system as enshrined in the General Agreement on Tariffs and Trade (GATT)/W'TO articles?

- What do these arrangements do to the core principle that drove the post-war multilateral trading system, viz., MFN treatment?

- Why have such arrangements mushroomed?

Specifically for Pakistan:

- What do these developments mean for the country's long-term development and its geopolitical position? This in turn involves answering two supplementary questions: (i) how has Pakistan responded to the general trend of increasing bilateralism? and (ii) are Pakistan's bilateral trading relations driven by some strategic longterm vision of the Pakistan economy?

This paper attempts to address these questions in rather broad terms. It consists of four sections. The first section examines the actual GATT/WTO position on regional free trade areas, including whether such measures are steps toward a liberal trading regime or antithetical to it. The issue here is how such arrangements conflict with or undermine established multilateral trade disciplines. This is followed by a discussion of the factors that have resulted in the rise of bilateralism. We then review Pakistan's own trade agreements, including the ongoing discussions on reaching similar

${ }^{1}$ Australia, New Zealand, Canada, Japan, Taiwan, and the US are listed as receiving MFN treatment in the European Union. 
arrangements with other trading partners. The concluding section explores how Pakistan might pursue its long-term development interests in the current environment of rampant bilateralism.

\section{Consistency of BTAs with Multilateral Trade Disciplines}

After the experience of mutually destructive protectionism in the 1930s, achieving progressively freer trade was set as GATT's paramount goal. It was pursued over succeeding decades basically through an expanding membership of the world trading body on the one hand, and launching a series of trade rounds that sought to reduce trade barriers worldwide on the other. The principle of MFN trading-a rejection of discriminatory tariff and trade preferences-was made the cornerstone of the multilateral trading system. This was spelled out in some depth and placed at the beginning of the articles establishing GATT and later W'TO. The relevant article states:

With respect to customs duties and charges of any kind imposed on or in connection with importation or exportation or imposed on the international transfer of payments for imports or exports, and with respect to the method of levying such duties and charges, and with respect to all rules and formalities in connection with importation and exportation ... any advantage, favour, privilege or immunity granted by any contracting party to any product originating in or destined for any other country shall be accorded immediately and unconditionally to the like product originating in or destined for the territories of all other contracting parties $[s i c]$.

A direct implication of this article is that granting preferential trading treatment to countries forming a customs union or a free trade area at the expense of other GATT/WTO member countries implies ipso facto a violation of the MFN principle. ${ }^{2}$ The exception, however, is provided in Article 24, which permits the creation of a customs union or a free trade area of fixed or interim character, but with the proviso that compensation is given to nonparticipating members in case they are hurt as a result. A further exception to the MFN rule was introduced in 1979-the so-called "Enabling Clause" - to allow developing countries to enter into regional trading arrangements with other developing countries. This clause allowed

${ }^{2}$ A customs union differs from an FTA in that it intends to institute a common tariff for its member countries on a specified date. 
developing countries to grant nonreciprocal and nondiscriminatory tariff preferences to other developing countries.

Under the GATT/WTO rules, free trade area or customs union proposals should, in principle, be notified "promptly" to the world trading body along with all the information needed for a proper review. This requirement, however, has been observed more in the breach than in compliance. One often cited reason is that the language of Article 24 is vague and subject to interpretation. According to Folsom (2008):

Article 24 standards for bilaterals are deceptively ambiguous, make little economic sense, and in application have proved a dismal experience, if not a fiasco. (p. 7)

Free trade agreement (FTA) reporting was expected to improve with the establishment of a WTO committee on regional trade agreements (CRTA) in 1995 , which was charged with the task of thoroughly examining each reported FTA. To further improve supervision, a "Transparency Mechanism" was also instituted in 2006 that spells out further the procedures for the notification and examination of all special trading arrangements. But little has been accomplished so far. The new steps have failed to "come to grips with the systematic ambiguities that led to Article 24's early and ongoing regulatory failure." (Folsom 2008, p. 9)

The question then arises why this lapse in the application of multilateral disciplines has been allowed to go virtually unchallenged within the WTO. After all, every preferential trading arrangement implies that there are winners (i.e., countries that gain market access) and losers (i.e., countries who lose market access.) Why have the losers not challenged such agreements under the WTO's Dispute Settlement System (DSS)? There are many reasons. One, because the trading agreements are overlapping (what Jagdish Bhagwati has called a "spaghetti bowl" of agreements), losers under one trading deal expect to be gainers under another. Thus, for example, Pakistan, despite losing market access in important products in the US as well as the European Union, is unable to challenge the preferential arrangements with other suppliers under the DSS.

In short, a Catch 22 situation seems to have arisen. Since it is virtually impossible to knock down the complex web of BTAs, every country ends up aspiring to form or join parallel arrangements. This is especially the case where it is leading industrial countries-the US, European Union, and Japan-who push for a trade agreement. Excluded developing countries end up virtually lining up as mendicants for similar 
recognition by the world's biggest trading nations. Pakistan is a case in point, which is discussed later.

There is also the consideration that taking a matter to the Dispute Settlement Body is an expensive proposition in terms of money and time, with uncertain outcome. In some cases, special trading arrangements are between developed and developing countries (notably, EU with ECA), which have been difficult to challenge for their partial conformity with the applicable multilateral rules. (Although it was a rather different situation, the US successfully challenged some years ago the EU's deeply entrenched preferences on banana imports under the Lomé Convention.) Another factor has been that, while the WTO articles continue to refer to "regional trade agreements," (RTAs) the current genre of special trading arrangements goes well beyond the usual tariff and protection issues and aims at what has come to be called "deeper integration." The WTO may not have the competence necessary to evaluate such agreements.

All the same, there are significant costs associated with RTAs: not just the static costs associated with "trade diversion" (which Viner pointed out many decades ago) but also the longer-term consequences for the growth and development prospects of individual countries. There are also increased transaction costs arising out of a lack of transparency while countries have become increasingly skeptical about the value of active participation in multilateral trade negotiations. Because trade agreements often overlap, the negotiation process is rendered opaque, their benefits and costs are difficult to measure, and their implementation difficult to monitor. Harrmonn (2008) notes:

... the sheer number of different RTAs with different partners, different preferences and with different $\mathrm{RoO}$ [Rules of Origin] ... imposes huge transaction (compliance) costs on private traders, which can only be borne by big multinational companies, but not by smaller businesses ... Bilateral trade agreements will not benefit the participants to the same extent, but that they will tend to favor the bigger partner (e.g., the USA or the EU) at the cost of the smaller partner, which will often be a developing country that has no real influence on the final outcome of the 'negotiations'. (p. 4)

In short, the weakening of the multilateral trading system has above all hurt developing countries, especially the smaller and economically weak, which are not particularly attractive to large economies for special commercial relations. (However, some of these countries do benefit from the General System of Preferences or GSP). With the diminution of the MFN's 
role in international trade, developing countries can no longer expect to take advantage of the "free ride." In the past, MFN treatment ensured that any tariff cuts negotiated by a group of countries were also applicable to them. The irony, however, is that developing countries still manage to unite in common purpose against specific proposals at the WTO (as, for example, against the Singapore issues) but are found willing to bargain away on those issues when negotiating a bilateral deal.

\section{Reasons for the Global Rise of Bilateralism}

The rise of bilateralism or regionalism in international trade is the consequence of a combination of factors. One factor has been developments within multilateral trading negotiations. The Uruguay Round negotiations were, in a sense, a watershed. While successful in generally lowering tariffs and extending multilateral disciplines to hitherto excluded areas (viz., services, intellectual property, and foreign investment), the Round conspicuously failed to make significant progress with respect to the two areas that were of key interest to the developing world, viz., agriculture and textiles.

This failure had two consequences. On one hand, the developing world became far more skeptical and suspicious of multilateral trade negotiations and become better organized, resistant, and united within the WTO in challenging proposals from industrial countries that were seen to be inimical to its common and shared interests. On the other hand, their success in the Uruguay Round made industrial countries even bolder and more ambitious in seeking what came to be called "deeper" global integration. This meant bringing into the multilateral framework other areas of special concern to the industrial North, i.e., trade facilitation, foreign investment, competition policy, and government procurement (the so-called Singapore issues $^{3}$ ) as well as environmental and workers' rights concerns. Independent of the W'TO, an attempt was also made by leading industrial countries to get an agreement on an international investment treaty.

The resistance to the idea of the Doha Round (also called, largely for PR reasons, the "Development Round") on the part of developing countries was basically rooted in their concern over the Singapore issues. Thanks to their united front and successful maneuvering, developing countries were able to halt negotiations on the draft investment treaty and successfully had the discussion of all but one of the Singapore issues (trade facilitation) excluded from the Doha negotiations at the 2003 WTO Ministerial Meeting in Cancun.

${ }^{3}$ These issues were made part of the multilateral negotiations at the 1996 WTO Ministerial in Singapore. 
Folsom (2008) gives the following assessment:

The failure to launch a new round of WTO negotiations in Seattle (1999), followed by delays and perceptions of possible failure in the Doha Round commenced in 2001, has contributed to a veritable feeding frenzy of bilaterals. Well over 100 new agreements have been notified to the WTO, and a large additional number are believed not to have been notified. In general, most of the notified agreements are bilateral, not regional in character. Meanwhile, the W'TO Regional Trade Agreements Committee, working by consensus, has been unable since 1995 to complete even one assessment of a bilateral agreement's conformity to GATT Article 24 or GATS Article 5. (p. 10)

Having failed within the multilateral setting, industrialized countries became interested in developing regional and bilateral relations to further their agenda. Evidently, this had two advantages: one, it could help to divide and weaken developing countries as a group within the W'TO negotiations; and, two, individual countries could pursue and promote commercial relations driven more obviously by their national interests. Such agreements had the added advantage that an industrial country (typically, the bigger, more powerful partner) could reward or punish countries on a selective basis, something that is totally opposed to the letter and spirit of GATT/WTO.

Bilatera1/regional trade agreements have, however, grown in number and importance among developing-country groupings. There are several reasons for this, ranging from national interest and the need for support to specific sectors (although this could work the other way also) to national security concerns (Kastner and Kim 2008). A certain herd-like behavior can also be observed. Commercial trade agreements are perceived to enhance individual countries' international commercial acceptability and competitiveness, which means that countries failing to join an agreement feel alienated and isolated.

There are some cases-notably that of the EU with respect to former colonies in Africa and the Caribbean-where preferential tariffs are applied for historical reasons or to help a group of countries (as, for example, under the GSP). The EU's recent push to have "economic partnership agreements" with African countries is driven both by self-interest and past colonial relationships. In the case of the countries of the former Soviet Union, regional trade was promoted in order to preserve traditional economic and trading links. Sometimes countries act to neutralize other competitors, e.g., when Japan signed agreements with Mexico and Thailand to counteract the 
commercial influence of the US in those markets. This may also have motivated Pakistan's initiative to reach bilateral agreements.

Geopolitical considerations are also often important, negatively as well as positively, in ad hoc trading arrangements that violate the MFN principle. Governments may worry that establishing close commercial ties with an adversary could make it economically stronger, as in the case of Pakistan's opposition to granting the MFN treatment to India or the US's use of trade sanctions against Iran or Cuba (not a WTO member and therefore not qualifying for MFN status). Alternatively, ad hoc trading arrangements may be designed to help an ally or reward it for cooperation in some international effort (counter-terrorism): again, for example, the temporary relaxation of quotas for Pakistan in the US and EU after 9/11.

The W'TO's failure to assert its authority in controlling or regulating the spread of BTAs has been another important factor. It was noted earlier that there is a special WTO committee on regional trade agreements, but it has not been particularly effective in reviewing reported trade agreements, let alone following up on ones that were not reported. Similarly the "transparency mechanism" of 2006, despite its earlier promise, has accomplished little.

\section{Pakistan Bilateral Trade Relations: An Overview}

Asia is one of the world's least closely integrated regions, notwithstanding the conclusion of a number of FTAs in recent years (Bhattacharya 2006). Even the ASEAN countries did not enter free trade area mode until 1992. According to the Asian Development Bank, some 154 BTAs had been signed among its member countries as of 2007. It is, however, the region's larger or more rapidly growing economies that have led the way in pursuing special trading arrangements. Singapore has the largest number of trade agreements, with a total of 31 FTAs, of which 20 are bilatera1. Other countries include Japan (15 bilateral, 18 total), China (14 out of 20) and Korea (13 out of 20) (Kastner and Kim 2008). Economic integration and trade relations within South Asia are even weaker, although some progress has been made in recent years.

Pakistan's Ministry of Commerce lists the following bilateral trade agreements on its website: Sri Lanka, Malaysia, China, and Iran as well as a pluri-lateral agreement among SAARC members, i.e., SAFTA. Pakistan has also been engaged in discussions with Bangladesh for some time but nothing concrete has materialized so far. 
A country's trade pattern provides a rough, albeit static, picture of the relative importance of bilateral trading relations. Table-1 gives the direction of Pakistan's foreign trade, identifying major destinations for its exports and major sources of its imports. The US and EU are by far the most significant markets for Pakistani exports, both accounting for roughly a quarter of the total. This concentration in trade has changed little over time. Other major destinations for Pakistani exports are Dubai and Saudi Arabia (both members of the GCC). Exports to Bangladesh, India, and Sri Lanka are modest, although their share of the total has risen a little over the past few years. However, taking the SAARC countries together, the subregion's importance for Pakistan has increased considerably, with its share in exports now standing at $10 \%$.

On the import side, again, the EU is the biggest source (around 15\% of the total), followed by two GCC countries, Saudi Arabia and Kuwait, which together account for some $16 \%$ of imports (predominantly oil) and China (10\%), whose exports to Pakistan, as to other destinations, have risen rapidly over the past decade. Once again, the SAARC countries are not particularly important as a source of Pakistani imports, though they do supply Pakistan with some much-needed imports.

In what follows, we focus on bilateral trade relations that can be deemed of strategic value to Pakistan in economic as well as political terms. These include the agreements already concluded, i.e., with China and the South Asian countries, as well as the ongoing discussions with the US, EU, and GCC on possible future free trade arrangements. Japan is another key trading partner for Pakistan, but the discussions remain stuck at an “exploratory” stage.

\section{Commercial Relations with China}

A Pakistan-China FTA was signed in November 2006. It calls for the elimination of tariffs on the part of China on $35.5 \%$ of imports from Pakistan within 3 years and another $34.5 \%$ of imports within 5 years, bringing the total to $70 \%$ of imports. Pakistan obtained tariff-free access to such products as industrial alcohol, cotton fabrics, bed linen and other home textiles, marble and other tiles, leather and sports goods, some fruits and vegetables, and some iron and steel and engineering goods. Pakistan agreed to eliminate tariffs on $35.6 \%$ of imports from China within 3 years and a further $19.9 \%$ within 5 years, i.e., a total of $55.5 \%$. The products covered consist principally of machinery, chemicals, fruits and vegetables, medicaments, and some raw materials for industry. Both parties committed themselves to "endeavour to eliminate the tariffs of no less than 90 per cent of products, both in terms of 
tariff lines and trade volume within a reasonable period of time on the basis of friendly consultation and accommodation of the concerns of both Parties."

To gain a sense of the importance of this agreement, it is helpful to look at the magnitude of trade between the two countries. Pakistani exports to China amount to less than $\$ 600$ million while its imports from China amount to roughly $\$ 3.5$ billion. In other words, in recent years, Pakistan's trade deficit with China has averaged close to $\$ 3$ billion.

However, the significance of the China FTA goes beyond purely trade. In fact, the development of closer economic ties in other spheres may be even more important. Close China-Pakistan ties started to evolve in the 1960s and are seen to be of strategic significance not just by the two countries concerned but also by other countries, notably India and the US. The FTA with China actually builds on a series of collaborative programs and investments over the past several years. These include the establishment of a China-Pakistan joint investment company, construction of a China-Pakistan friendship center in Islamabad, financing for China-Pakistan bilateral cooperation, construction of schools and hospitals in the earthquake-hit areas of Pakistan, financial support for upgrading and rehabilitating the Karakoram Highway, financing of the Gwadar port phase-I, framework agreement between China's Northern Industries Corporation and Heavy Engineering Complex Taxila, Huawei-TMLGSM phase-5 expansion project agreement (telecommunications), signing of a memorandum of understanding (MoU) between the China-Zhenhua oil company and Pakistan's Ministry of Petroleum and Natural Resources, exploration and development of Saindak East Ore Body in Pakistan, and collaboration in Engro-Asahi Polymer and Chemical Limited of Pakistan (PVC producer). ${ }^{4}$

\section{Commercial Relations with the US}

The US is the only major economy with which Pakistan has enjoyed a trade surplus for some time. Even during the troubled year of 2008, US exports to Pakistan amounted to $\$ 1.76$ billion in the first 10 months, while Pakistan exports to the US amounted to $\$ 3$ billion over the same period. For the year 2007, US exports amounted to \$2 billion (which included $\$ 452$ million for the purchase of civilian aircraft) compared to Pakistan's exports of $\$ 3.6$ billion. Three quarters of Pakistan's exports consist of apparel and cotton bed linen and towels, etc.

\footnotetext{
${ }^{4}$ This list is reported in an article on a website concerned with American diplomacy and strategy, and voiced some concern over the development of close economic and commercial ties between Pakistan and China.

(http://mountainrunner.us/2006/11/china_pakistan_and_free_trade.html)
} 
Close defense and economic relations between the two countries have a long history. However, the only nondefense and commercial bilateral agreement reached between the two countries was the so-called Pakistan Friendship and Commerce Treaty, which was signed in 1959 and came into effect in 1961. While it sought to foster a good working environment for the two countries and supported economic, cultural, and social exchanges, it did not offer anything specific with respect to the lowering of tariffs and other barriers to trade on either side.

More recently, following 9/11 and with the renewed interest on the part of the US in Pakistan as a "strategic ally," trade between the two countries received a significant stimulus. Pakistan has actively sought an FTA with the US, especially since the start of discussions for closer economic and commercial ties between the latter and India. The US, however, has remained lukewarm toward Pakistani overtures, although it continues to urge Pakistan to improve its foreign investment environment as a step toward working out a bilateral investment treaty (BIT). ${ }^{5}$

The one-sided nature of the discussions between the two countries is well captured in a news report of 2006, covering the meeting between Under-Secretary of State for Trade and Commerce, Franklin L. Lavin, with Pakistan's commerce minister:

The United States has appreciated Pakistan's trade and investment policies as liberal and attractive and has suggested to the government of Pakistan to arrange a meeting with all US companies working in Pakistan at a proper forum to know their concerns about making investment in Pakistan and subsequently devise a mechanism to address their concerns ... Pakistan should [also] identify and negotiate with major US companies that are now not working in Pakistan and try to address their investment-related concerns so that they also can invest in Pakistan. Daily Times, 6 May 2006.

The US, however, has been quite unambiguous in spelling out its main interests in Pakistan, which include increased cooperation in the fields of intellectual property rights (IPRs) and energy, elimination of terrorist financing, creation of the so-called Reconstruction Opportunity Zones in the Tribal Areas, and improved transit trade to Afghanistan. Specifically with respect to trade, the

\footnotetext{
${ }^{5}$ At the conclusion of President Bush's Pakistan visit in March 2006, a Joint Statement was issued on the so-called United States - Pakistan Strategic Partnership, which called for facilitating "Pakistan's economic growth through increased trade and investment links with the United States ...” Nothing concrete was achieved subsequently.
} 
US is not willing to go beyond the General System of Preferences (GSP) under which only a small portion of Pakistani exports qualifies for duty-free access.

\section{Commercial Relations with the EU}

The EU's response to Pakistan's overtures for an FTA has been similar to that of the US, i.e., it has promised nothing. In order to give a semblance that the issue is not altogether dead, the two parties agreed to the setting up of the "Pak-EU Joint Commission" as part of a cooperation agreement between the two. The mandate of the Joint Commission is broad, and four subgroups were set up to address issues related to trade, development and economic cooperation, migration and civil issues, and science and technology.

The subgroup on trade last met in May 2007, and the sharp divergence of goals between the two trading partners became readily evident. Pakistan sought to achieve a "durable, predictable and reciprocal trade relationship with the EU in the form of an FTA." The EU's response was simply that its trade relations were basically governed by its "Global Europe Strategy”, under which multilateralism (i.e., the WTO negotiations) is held to be the preferred option (Government of Pakistan, Ministry of Commerce, News and Press Release, 30 May 2007). But, significantly, the EU representative made it clear that the EU's criteria for entering into an FTA rested basically on two considerations: (i) market size and growth potential, and (ii) the level of protection against EU exports. On both grounds, India could be seen to qualify while Pakistan did not, as the latter had neither the requisite economic weight nor was its protection level sufficiently high. Considering that the EU currently extends MFN treatment only to a handful of countries, this position appears to be a little disingenuous. The only concrete outcome of the meeting, however, was that both parties agreed to conduct a study of the impact of trade policies on the two trading parties.

While there was little progress with respect to its access to the European market, Pakistan was made to yield in one key area, i.e., protection to its automotive industry. The bone of contention was the socalled capital value tax (not strictly speaking an import barrier) on imported vehicles, which Pakistan was made to eliminate outside of the WTO negotiations. But the EU still objects to Pakistan levying higher import duties on bigger car engines, an area of special interest to the EU.

\section{Commercial Relations with the GCC}

Pakistan has actively pursued the establishment of a bilateral trading relation with the GCC, and a framework agreement was signed several years 
ago. But there is no indication as to when the final agreement will be concluded. The GCC is an important destination for Pakistani exports (about $8 \%$ of the total goes to Dubai and Saudi Arabia alone) and the main source of its critical import, oil, which constitutes a little under one fifth of the total import bill in recent years. Pakistan's total trade (i.e., including imports and exports) with this region now amounts to about $\$ 5.5$ billion.

Close economic relations with Saudi Arabia, the UAE, and other countries of the GCC have existed for a long time but Pakistan is unlikely to gain much through an FTA. The GCC consists of economies that are basically open, with low to zero protection on their imports. Thus, the margin of preference that Pakistan might gain in this market as a result of elimination of tariffs is unlikely to amount to very much. Oil imports are of course critical for the growth and wellbeing of Pakistan's economy, but they too are unlikely to be affected in any significant fashion by the creation of a free trade area. One unintended beneficiary of closer trade ties with the region might actually be India, for in recent years a large amount of Indian exports to Pakistan have been routed through Dubai. All the same, the GCC is of strategic importance to Pakistan for a variety of reasons-not least because of the large number of Pakistani immigrants-and closer economic integration within the region could possibly be mutually beneficial.

\section{Commercial Relations with SAARC and India}

The South Asian countries, including India, are still behind East Asia in terms of regional integration. Only about $5 \%$ of the trade of all SAARC members is with each other, compared to $25 \%$ within ASEAN, $43 \%$ within NAFTA, and 66\% within the EU (Hartwick 2008). There are several reasons for this. One, notwithstanding India's spectacular economic performance over the past decade, the region remains industrially less advanced than East Asia. Thus, the usual driver of economic integration-manufactured exports-has been relatively weak and regional trade flows are not of great economic consequence. Closely related is the fact that the South Asian countries compete in similar markets, mostly textiles and garments. A recent study shows that Pakistan's export structure is quite similar to that of Bangladesh, India, and Sri Lanka, and the similarity with India's exports is even greater. ${ }^{6}$

\footnotetext{
${ }^{6}$ According to the CARIS study (2008), the export similarity index with respect to Pakistan was estimated at 0.22 for India, 0.18 for Bangladesh, and 0.15 for Sri Lanka for 2005. A value of 1.0 of the index implies a perfectly identical pattern of trade. The study further notes that "... there was a relatively high degree of similarity between the EU's imports from Pakistan and its imports from India, and considerably higher than when comparing with China, the GCC or Korea. However, we also note that over time
} 
This means that a mutual lowering of import barriers within the region can be expected to have stronger "trade diversion" effects than "trade creation" effects, at least in the short term. In other words, the immediate benefits from integration appear to be rather small for these countries. However, the foremost reason for the weak commercial links within South Asia has been the long history of political tensions between India and Pakistan. Given these considerations, it was an achievement in its own right that a trade agreement among the South Asian neighbors-SAFTA-was actually concluded at the SAARC summit in January 2004 and came into force 2 years later.

Although there are sensitive lists put up by each member country and the rules of origin are stringent, SAFTA offers the prospect of significantly lowering import barriers. The agreement provided for a trade liberalization program under which India, Pakistan, and Sri Lanka were expected to bring down their custom tariffs by $20 \%$ by the start of 2008 , while the other four countries' tariffs-Bangladesh, Bhutan, Nepal, and the Maldives-would be reduced by $30 \%$. However, it is too early to judge the economic significance of the trade agreement.

Before concluding this section, we need to address specifically Pakistan's commercial relations with India. This is for two reasons. One, the success of SAFTA will ultimately depend on how the region's two leading economies conduct and foster commercial relations with each other over the coming period; and, two, rightly or wrongly, Pakistan's commercial relations with other countries-the US, EU, GCC, or other South Asian countriesare not altogether independent of India's own forays in the same markets. ${ }^{7}$

In Pakistan, there has been keen debate on the case for opening up trade with India (see, for example, Naqvi and Nabi 2008). Were there a modicum of harmony at the political level between the two countries, the case for greater economic integration would be obviously very strong. But in the pursuit of closer economic ties between the two countries, historical concerns, real and perceived, cannot be conveniently put aside. Thus, before significant improvements take place, both countries will need to take a number of "confidence building measures." At the top of the list of concerns must be a mutually satisfactory resolution of the water issue. The Indus Basin Treaty served the two countries well for over 4 decades, but problems have resurfaced in recent years on the question of water use and

[i.e. over 1996-2006] the degree of similarity with India has substantially reduced” (p. 41).

${ }^{7}$ The outcome of India's discussions on free trade with the US and EU will obviously have an impact on Pakistan's access to these markets. But India is also eagerly seeking an FTA with the GCC. 
distribution. Water in its rivers is a lifeline for Pakistan and the issue needs to be addressed on a priority basis.

The other consideration is that, given the relative strengths of the two countries' export sectors, the opening up of trade will probably have to be phased and managed carefully on the part of Pakistan. "Rationalists" may believe in the power of comparative advantage and hold that increased competition is what Pakistan's industry needs, but the fact is that, as discussed later, the general lowering of import barriers has not yet resulted in significant improvements in Pakistan's international competitiveness. Ensuring that the domestic industry survives and thrives in the face of foreign competition is a legitimate concern, one that has generally guided policymaking in successful economies. Thus, for example, Korea would not allow import of Japanese automobiles into its market as late as the early 1990 s on the grounds that its own automobile industry might be stifled due to Japanese competition.

This does not suggest that the matter of opening up trade relations with India should not be given the priority it merits. Pakistan must prepare itself carefully for competition from a bigger and stronger neighboring economy if economic relations are to evolve in a mutually beneficial direction. This may require time as well as strategic policymaking, a subject addressed in the next section.

\section{Promoting Pakistan's Trading Interests}

Consequent to the implementation of trade liberalization over the past decade, Pakistan's average customs tariff has come down to about $14 \%$. Pakistan has also taken steps to improve its business environment. It is now a country that stands more favorably in the World Bank's Doing Business index than many other countries in East and South Asia. According to this index, Pakistan's business climate is better than that of China and much better than any of the other South Asian countries, including India ${ }^{8}$ (Table2). These are noteworthy achievements but the fact remains that Pakistan's performance in the world market remains less than satisfactory. Its industry has been largely unable to compete in terms of quality or cost with the rising tide of imports from other low-wage countries, most notably, China. Compared to the other rapidly growing Asian economies, Pakistani exports

\footnotetext{
${ }^{8}$ The Doing Business index is seriously flawed, but continues to be used widely. What the comparisons made here demonstrate is that there are other considerations more critical for business decisions than those captured by the index. This is why investors continue to find China or India, for example, far more appealing places to do business than Pakistan.
} 
have increased only modestly and have undergone little diversification in terms of products or markets.

The result is that, over the years, Pakistan's trade deficit has continued to rise, reaching a level of $\$ 15$ billion or about $10 \%$ of GDP in 2008. This was the single most important cause of the economic crisis that hit Pakistan that year (Haque 2009). The program of privatization, liberalization, and deregulation that the government adopted in order to increase domestic competition and make Pakistani industry more efficient has largely failed to achieve its intended purpose. However, the rapid rise in foreign direct investment (FDI) in recent years could possibly be attributed to the reform program, but that too did little to enhance Pakistan's international competitiveness. FDI flowed largely to the telecommunication sector and development of real estate rather than into new industry.

The starting point for establishing robust international trading relations is the health of the domestic economy. Sick economies do not, as a rule, make good trading partners. In this respect, there is a consensus in Pakistan's policy circles that reducing the domestic and external macroeconomic imbalances to a sustainable level and bringing down inflation to a rate comparable to the country's trading partners is a priority area for policy action in Pakistan. Beyond that, there are two areas that merit much closer attention than they have been given hitherto: (i) the measures targeted at improving Pakistan's international competitiveness, and (ii) a program to rationalize the country's trade policy.

International competitiveness has been defined in different ways but at its core it implies a country's ability to compete in the world market while ensuring that its living standards continue to rise, which is possible only if labor productivity improves over time. Thus, measures designed to reduce real wages in order to cut production costs (for example, through an exchange rate adjustment) can yield only a temporary competitive advantage. It is unfortunate that in Pakistan the discussion on competitiveness focuses on adjusting the exchange rate rather than bringing about fundamental technological improvements. (See Haque 2009, where this issue has been addressed in some depth.) What is required instead is a national development strategy that, on the one hand, explicitly aims to improve productivity at the industry level (or even in some cases firm level) and, on the other, seeks to ensure that the economic structure moves over time toward higher value-added activities (Haque 1995). Toward that end, market signals obviously play a very important guiding role, but seldom do they bring about on their own the needed structural changes in developing countries. Strategic industrial protection and promotion may also be 
necessary, as has been amply demonstrated by the experience of successful economies in East Asia and elsewhere.

But the limitations of trade policy must also be recognized. Firstly, the freedom to raise tariff barriers or grant subsidies to industry is now greatly circumscribed under the WTO rules. Secondly, badly designed trade policy can do much harm, which is evident from the experience of failed industrialization in developing countries. Although Pakistan now has generally low tariffs, there may still be scope for making trade policy more effective by removing redundant protection, i.e., where tariffs or other barriers are not the binding constraints on imports or do not serve any specific purpose. Further streamlining customs procedures and eliminating cumbersome controls could also help both importers and exporters. But, ultimately, a rational trade policy requires that policymakers are clear about the goals of using this instrument. ' In other words, Pakistan's national interests can only be pursued if they have been clearly defined.

Beyond the promotion of industry, trade policy is also useful in multilateral trade negotiations as a "bargaining chip" and in seeking to improve access to foreign markets. Given the proliferation of preferential trading arrangements, driven as they are by national, strategic interests, countries like Pakistan face serious hindrances in their access to world markets. As we have seen in the previous section, Pakistan's position is such that it is seen neither as a sufficiently important candidate for preferential trade agreements nor does it qualify for special preferences reserved for least-developed countries.

The following examples illustrate well the challenges Pakistan faces in two of its major export markets, the US and EU.

The first case is that of Pakistani towel exports to the US, which face a tariff duty of $9.1 \%$. This rate of duty is about seven times the average American tariff rate (Gresser 2008). At the same time, towel imports from other significant suppliers (which include Mexico, Canada, and Israe1, all more advanced countries) face no tariff at all thanks to preferential trading arrangements. In critiquing US commercial policy toward Pakistan, Gresser (2008) notes:

Towels are not an exceptional case; they are in fact wholly typical of the American trade relationship with Pakistan ... In

\footnotetext{
${ }^{9}$ The design of policy to promote national economic development is further discussed in Haque (2007).
} 
practice, the American trade regime hinders Pakistan more than it helps it. On the one hand, it treats Pakistani products far more harshly than those of wealthy countries ... On the other hand, through FTAs and preferences programs, Washington exempts from tariffs identical goods made in about 70 other developing countries. (p. 200)

The second case relates to the Pakistani export of ethanol to the EU (see Ahmad (2008) for a detailed discussion). Although the item is an insignificant export for Pakistan, it nevertheless illustrates the power of tariff barriers in industrialized countries. After the EU granted duty-free access to ethanol from Pakistan in 2002, exports rose dramatically during the following 3 or 4 years, peaking at about $\$ 40$ million in 2005. Pakistan quickly became the largest exporter of ethanol to the European market, and started to invest in distilleries to meet the rising demand. But in 2005, the EU not only withdrew all tariff concessions but also started anti-dumping investigations. According to Ahmad (2008):

This resulted in a levy of $\$ 190$ per ton of import duty and Pakistan's exports to EU started falling rapidly. Most of its seven distilleries -- which could produce 1 million litres a day - and another five new distilleries - which were in the process of being set up to produce another 0.5 million litres a day - had to scale back their production. (p. 56)

This example is again symptomatic of the harm that protection in industrialized countries can do to developing country exporters. Thus, for example, when the EU chose to include Pakistan in the general preference scheme and eliminated duties in 2002, the export of textiles and clothing rose dramatically in the following 2 years, but collapsed following the withdrawal of the concession (Ahmad 2008).

The reality is that Pakistan is unlikely to be offered an FTA in the foreseeable future either by the US or EU. To cope with this situation, Pakistan might possibly consider a two-pronged approach. On the one hand, it could become a champion of multilateralism at international forums and attempt to mobilize support from among other similarly placed countries. Although arresting the rising tide of bilateralism is likely to be a hard struggle, there is considerable support for this position within the WTO and other influential circles in industrialized countries. At any rate, "naming and shaming" countries in multilateral negotiations could at least open up the discussion on restoring MFN treatment to its rightful place. 
On the other hand, as a complement, Pakistan should start to insist that its major trading partners, notably, the US, EU, and Japan, grant noless favorable treatment to that being granted to Pakistan's developing country trading rivals. The point of this would be that if a major industrial country enters into an FTA with one of its commercial rivals, Pakistan should seek to be given comparable treatment in the same markets. The WTO articles provide for compensation where "injury" is demonstrable. Alternatively, this special treatment could be sought as a supplement to the aid programs that the three countries are considering for Pakistan as a "strategic" country.

To sum up, refocusing Pakistan's trade strategy involves the following four steps:

- Restore its macroeconomic balances (i.e., fiscal and trade deficits) to sustainable levels;

- Take measures to improve its international competitiveness through productivity improvement, which must include improving and standardizing the quality of Pakistani exports;

- Rationalize its trade policy and define its strategic interests; and

- Take advantage of its perceived "strategic" position in geopolitics by seeking favorable treatment in its major markets. 
Table-1: Direction of Pakistan Trade

\begin{tabular}{|c|c|c|}
\hline & 1999-2000 & $2005-2006$ \\
\hline \multicolumn{3}{|c|}{ Pakistan's Major Export Markets (\% average) } \\
\hline USA & 23.3 & 24.7 \\
\hline Germany & 6.3 & 4.5 \\
\hline UK & 6.7 & 5.8 \\
\hline EU & 27.5 & 26.8 \\
\hline Japan & 3.3 & 1.0 \\
\hline Hong Kong & 6.6 & 4.0 \\
\hline China* & 2.7 & 3.0 \\
\hline Dubai & 5.6 & 4.5 \\
\hline Saudi Arabia & 2.5 & 2.3 \\
\hline India* & 0.7 & 1.9 \\
\hline Bangladesh* & 1.4 & 1.6 \\
\hline Sri Lanka* & 0.7 & 1.1 \\
\hline SAARC* & 6.3 & 10.4 \\
\hline \multicolumn{3}{|c|}{ Pakistan's Major Import Sources (\% average) } \\
\hline USA & 7.0 & 6.7 \\
\hline Germany & 4.1 & 4.6 \\
\hline UK & 3.9 & 2.7 \\
\hline EU & 15.0 & 16.3 \\
\hline Japan & 7.3 & 6.3 \\
\hline China* & 5.0 & 9.8 \\
\hline Saudi Arabia & 7.9 & 11.6 \\
\hline Kuwait & 9.0 & 5.4 \\
\hline Malaysia & 5.5 & 2.8 \\
\hline India* & 1.7 & 3.7 \\
\hline Bangladesh* & 0.3 & 0.2 \\
\hline Sri Lanka* & 0.3 & 0.2 \\
\hline SAARC* & 2.7 & 4.4 \\
\hline
\end{tabular}

Source: Compiled from Ministry of Commerce data and CARIS (2008). 
Table-2: “Doing Business” 2009 Ranking - Pakistan's comparators (77)*

\begin{tabular}{cl}
\hline Better than Pakistan & Worse than Pakistan \\
\hline Thailand (13) & China (83) \\
Malaysia (20) & Vietnam (92) \\
Korea (23) & Sri Lanka (102) \\
Turkey (59) & Bangladesh (104) \\
& Nepal (121) \\
& India (122) \\
& Indonesia (129) \\
& Philippines (140) \\
\hline
\end{tabular}

Notes: The position in the country ranking is given within brackets.

Source: World Bank, Doing Business 2009. 


\section{References}

Ahmad, M. (2008). Achieving \$45 Billion Export Target by 2013: The Way Forward for Pakistan. In Kugelman and Hathaway (ed), Hard Sell: Attaining Pakistani Competitiveness in Global Trade, Woodrow Wilson International Center for Scholars, Washington DC.

Bhagwati, J. (2008). Termites in the Trading System. A Council of Foreign Relations Book, Oxford University Press, New York.

Bhattacharya, B.N. (2006). Understanding the Latest Wave and Future Shape of Regional Trade and Cooperation Agreements in Asia. CESIFO Working Paper No. 1856, November 2006. Paper presented at CESIFO Venice Summer Institute Workshop on "Understanding the Latest Wave and Future Shape of Regional Trade and Cooperation Agreements.”.

Centre for the Analysis of Regional Integration at Sussex (CARIS) (2008). The Impact of Trade Policies on Pakistan's Preferential Access to the European Union. Reference No. Trade08/C3/C18. University of Sussex, UK.

Folsom, R.S. (2008). Bilateral Free Trade Agreements: A Critical Assessment and WTO Regulatory Reform Proposal. Research Paper No. 08-070, University of San Diego School of Law, San Diego.

Gresser, E. (2008). The Paradox of the Towe1: Pakistan in U.S. Strategy and Trade Policy. In Kugelman and Hathaway (ed), Hard Sell: Attaining Pakistani Competitiveness in Global Trade, Woodrow Wilson International Center for Scholars, Washington DC.

Haque, I., and Others (1995). Trade, Technology and International Competitiveness. Economic Development Institute of the World Bank, EDI Development Studies, The World Bank, Washington DC.

Haque, I. (2007). Rethinking Trade Policy. UNCTAD Discussion Papers, No. 183, April 2007. UNCTAD, Geneva.

Haque, I. (2009). Pakistan: Causes and Management of the 2008 Economic Crisis. A paper submitted at the TWN/CAP conference on "The Effects of the Global Financial Crisis on Asian Developing Countries and Policy Responses and Lessons,” 18-20 August 2009, Penang, Malaysia. 
Hartwick, D.A. (2008). Pakistan and its Neighbors: Trade Challenges Ahead. In Kugelman and Hathaway (ed), Hard Sell: Attaining Pakistani Competitiveness in Global Trade, Woodrow Wilson International Center for Scholars, Washington DC.

Herrmann, C. (2008). Bilateral and Regional Trade Agreements as a Challenge to the Multilateral Trading System. EUI Working Papers Law 2008/09, Department of Law, European University Institute, Italy.

Kastner, S.L., and Kim, S.Y. (2008). Why the Rush on Bilateral Free Trade Agreements in the Asia-Pacific? Paper prepared for the International Studies Association Annual Meeting, San Francisco, CA..

Kazmi, S. (2006). Market Access Through Free Trade Agreements: Pakistan's Experience. SDPI Research and News Bulletin, $13(4$ \& 5). Kugelman, Michael and Hathaway, R.M. (2008). Hard Sell: Attaining Pakistani Competitiveness in Global Trade. Woodrow Wilson International Center for Scholars, Asia Program, Washington DC.

Naqvi, Z.F., and Nabi, I. (2008). Pakistan-India Trade: The Way Forward. In Kugelman and Hathaway 2008.

Syed, A.H. (2007). Effectiveness of Bilateral vs. Multilateral Trade. Paper prepared for presentation at the session "International Trade" of "International Conference of Young Economists", 16 - 20 June, 2007. Dhaka, Bangladesh.

World Trade Organization (2007). Trade Policy Review: Report by the Secretariat - Pakistan. WTO, Geneva. 